\title{
El cómic como espacio abierto Posibilidades expresivas a través del formato
}

\author{
Enrique Bordes y Ana Merino
}

La ductilidad del cómic abarca múltiples esferas, desde su proceso de elaboración hasta la distribución. Saltar de la viñeta a la página, concretar ese plano en dos dimensiones de variables infinitas (¿una cuartilla? ¿un tabloide?) y desplegar su sucesión en contextos igualmente múltiples (¿unos papeles con grapas? ¿las paredes de un museo? ¿un mural urbano?...) Esta mirada estimula reflexiones que se fraguan desde los formatos proyectados, vinculados al proceso de producción, al de la exposición o el ámbito intelectual de su creatividad expresiva, donde se condensa la dimensión gráfica.

El cómic como espacio abierto es un terreno analítico expandido de las posibilidades del medio. Nos permite estudiar y entender la evolución de los formatos como entornos estéticos narrativos, sociales, experimentales... Este dossier, dividido en dos entregas, presenta diferentes dialécticas articuladas con generosidad a partir de la convocatoria para analizar el cómic desde esta perspectiva.

Inician la reflexión las voces de Álvaro Pons y Noelia Ibarra, desde la experiencia de trabajar la sala de exposiciones de un museo, como lugar de experimentación formal en el que el cómic debe enunciarse. La muestra El dibujado de Paco Roca abarca las dinámi- cas del diseño expositivo en el diálogo del comisario con la voz del autor y su propuesta gráfica. Continuando esta meditación sobre el espacio museístico el ensayo de Santos M. Mateos Rusillo ahonda en los retos que enfrentan los museos de arte al incluir al cómic en su programación. Los interrogantes de ¿qué exponer? y ¿cómo exponerlo? construyen estimulantes reflexiones críticas donde museología y museografía se abren a otros lenguajes.

Por otra parte, la propuesta de Jordi Canyissà se centra en el formato como estímulo creativo y refuerzo de la ficción analizando Las ciudades oscuras, de François Schuiten y Benoît Peeters. Explica así, todo el entramado de sus ediciones, reimpresiones y los saltos de medio de una idea, desde la temporalidad de la revista a la condensación integral del tomo o la conversión del concepto en ambientación metropolitana. Siguiendo el hilo de lo seriado, la propuesta de Hugo Hinojosa y Claudio Aguilera se enfoca en la obra de Hervi para la revista chilena La Chiva. En este caso, la evolución de su contenido se entiende desde el formato físico de la publicación y en el diálogo abierto con el contexto político, social y urbano. 
El espacio abierto también ahonda en la voz autoral como experiencia de vida, en esta ocasión, Magda Mengual Morata y Jordi Giner Monfort, estudian la evolución de Julie Doucet y cómo el desencanto personal en el espacio social del cómic underground le lleva a la experimentación gráfica. Esta primera parte del dossier se cierra con la mirada de Jorge Belmonte, enfocada en las posibilidades comunicativas del cómic desde los parámetros intermediales e intertextuales de los superhéroes, reinterpretando las feminidades a través de un personaje icónico y su expansión.

Quedamos muy agradecidos por las reflexiones aportadas por nuestras compañeras y compañeros y seguiremos desplegando este espacio abierto en el segundo volumen... 